\title{
Productive and Reproductive Perfomance of Dairy Cows During Peripartum
}

\author{
Adalgiza Pinto Neto $^{1^{*}}$, Juliano Menegoto ${ }^{1}$, Fernando Skonieski ${ }^{1}$, Marcelo Falci Mota ${ }^{1}$, \\ Antônio Campanha Martinez ${ }^{4}$, Luiz Sérgio Merlini' ${ }^{2}$, Rodolfo Cassimiro de Araujo Berber ${ }^{3}$ \\ ${ }^{1}$ Universidade Federal da Fronteira Sul, Realeza, Paraná, Brazil; ${ }^{2}$ Universidade Paranaense Umuarama, Paraná, \\ Brazil; ${ }^{3}$ Universidade Federal de Mato Grosso, Sinop, Mato Grosso, Brazil; ${ }^{4}$ Universidade Estadual de Maringá, \\ Umuarama, Paraná, Brasil.
}

\begin{abstract}
Dairy activity is of great importance for the national economy. It is also an important source of income for families in the south east region of Parana that work in this area. There has been a notable expansion in the activities as well as in the quantity of production and the quality of the products. With this has come problems in the reproductive efficiency of the dairy cattle principally in relation to those with the greatest production. The objective of this study was to evaluate the productive profile and the reproductive efficiency of dairy cows. The evaluation covered 30 days before calving and 15,30, 45, 60 and 90 days after the calving. The study covered cows from two properties in the Municipality of Realza-PR in Brazil. In order to do the aforementioned, we used the Body Condition Score (BCS). We evaluated the production of milk and through the use of gynecological exams and we looked at uterine involution (UI) and ovarian cyclicality. The results showed falls in the BCS in the prepartum period and in the first weeks of lactation $(p<0.05)$ and the differences in the BCS were based on the season of the year in which the calving took place $(p<0.05)$ with the highest BCS being noted to occur in the hot seasons. The UI correlates with the presence of corpus luteum where animals were late in their uterine involution and had delays in their first postpartum ovulation ( $p<0.05)$. The average service period and calving interval were similar to those described for dairy cattle, however, we observed variations based on the seasons of the year which was possibly related to the greater availability and quality of the forage in the hot seasons.
\end{abstract}

Keywords: Dairy cows, BCS, uterine involution, postpartum ovulation

* Author for correspondence: adalgiza.uffs@ gmail.com 


\section{INTRODUCTION}

The production of milk has been shown as one of the main agricultural activities in Brazil. The state of Paraná occupies third position in the national ranking behind Minas Gerais and Rio Grande do Sul ${ }^{(1)}$.

The average productive rate for cows in the State of Paraná is higher than the national average reaching 8.8 liters/cow/day. The south east region is one of the regions that has been highlighted in production and growth obtaining, in the period between 2008 and 2012, an increase of $67 \%$ in the volume of production with only $15 \%$ more in the number of animals ${ }^{(2)}$. This incremental production is principally due to: the genetic evolution of the cattle, improvements in management systems and improvements in the food given to the animals ${ }^{(2)}$.

Low reproductive efficiency may have a negative influence on the productivity of the cattle with longer calving intervals (IEP) reducing the number of days of lactation during the useful life of the animal. This was frequently observed in the dairy cattle with the greatest production ${ }^{(3,4)}$.

Although the pathogenesis of the sub-fertility is multifactorial, what stood out was the delays in the cyclicality and the low rate of conception relating principally to the negative energy balance (NEB). The NEB which is established in the last weeks leading up to the calving and which is accentuated after the calving, occurs due to the energy demands of the cow being higher in relation to their ingestion capability. In this way, the animals enter into a catabolic state. They start to use their body reserves in order to maintain an elevated level of production. This means prioritization in nutrients for the production of milk at the detriment of the other functions, principally reproduction ${ }^{(5,6)}$.

The attributing of the BCS values is a subjective way for evaluating the energy reserves of an animal permits an estimation of the NEB intensity. The evaluation may vary in accordance with the method, but in general, the highest values indicate the greater quantity of body reserves ${ }^{(7)}$. We looked to identify which of the animal groups suffered the greatest negative impacts due to NEB and to estimate what was the level of interference in the reproduction. We sought to understand in which phase of the process was there the greatest influence which was fundamental to the efficiency of the dairy activity in the south east region of Paraná. This region is noted for having heterogeneous cattle with reference to their genetic potential and their level of production $^{(8)}$.

Therefore, in light of the above, this study aimed to evaluate the productive profile and the reproductive efficiency of dairy cows in the Municipality of Realeza-PR.

\section{MATERIAL AND METHODS}

75 Holstein cows were evaluated that gave calving between September 2014 to June 2015 in the first months of spring, summer and autumn. They came from two dairy herds located in the Municipality of Realeza, in the south east region of Paraná, Brazil. The Municipality of Realeza is located at an altitude of 520 meters, a latitude of $25^{\circ} 46^{\prime} 08^{\prime \prime} \mathrm{S}$ and a longitude of $53^{\circ} 31^{\prime} 57^{\prime \prime} \mathrm{W}$. The climate type is Cfa which is characterized as being mesothermal, sub-tropical and humid ${ }^{(9)}$.

The animals that were studied were kept in semi-confinement where they received food based on grass and supplements that contained corn silage (33.3\% dry matter, 7.6\% crude protein, $49.4 \%$ neutral detergent fiber, $23.5 \%$ acid detergent fiber and 3.4 ashes), concentrated protein (22\%), hay and minerals nucleus (Novo Bovigold ${ }^{\mathrm{R}}$. Tortuga. Mairinque-SP. Brasil). 
After making note of the age, number and date of calving, we the set the commencement date for the evaluation of each animal (30 days pre-partum).

The BCS was evaluated as well as the diary production at the 30 days prepartum period. The aforementioned was then done at calving and then postpartum on the following day intervals: $15,30,45,60$ and 90 days postpartum. In order to measure the BCS, the descriptions were based on Edmonson et al. ${ }^{(7)}$, and were done through the classification of the animals on a scale of one to five with the intervals of 0.25 points, where BCS 1 represented the animal that was exactly slim and the BCS 5 represented an animal that was obese. The diary production was measured in liters per day using the data from the controlled dairy farms.

At 30 and 60 days postpartum, we carried out gynecological exams with the use of ultra-sound equipment that was equipped with a linear retal transducer working at 7.5$\mathrm{MHz}$, in order to evaluate the uterus and the ovaries. The idea was to identify the uterine involution (pelvic uterus, small, symmetric and without content) and the presence of the corpus luteum).

We noted the dates and the number of inseminations that were used in each animal and 30 days after the coverage we carried out gynecological exams in order to diagnosis the gestation. The animals were kept in the study until there was a positive diagnosis of gestation.

The data that was obtained was submitted for Variation Analysis and the averages were compared using the Duncan Test. The presence of any correlations was tested using Pearson's method with the consideration of a 5\% significance using the Statistical program $\mathrm{SAS}^{\circledR}$.

\section{RESULTS AND DISCUSSION}

Table 1 shows the average of zootechnical data of the animals studied, being that the average number of calving for the animals was $2.88 \pm 1.7$ of calving with $20.58 \%$ (14/68) being primiparous and $61.76 \%$ (42/68) had two to four calving. $17.64 \%$ $(12 / 68)$ had for five or more calving.

The average production of the animals in the first three months of lactation was $24.3 \pm$ 4.2 liters of milk/day with a peak in production that was observed at the 60th day of lactation with an average of $27.00 \pm 5.91$ liters/cow/day

Table 01. Average and standard deviation of zootechnical data of the animals studied.

\begin{tabular}{ll}
\hline Zootecnical data & Average \pm SD \\
\hline Calving number for animals & $2.88 \pm 1.7$ \\
Milk production per day (liters) & $24.3 \pm 4.2$ \\
Milk production per animal (liters) & $27.0 \pm 5.9$ \\
\hline
\end{tabular}

The production of the milk had a correlation with the BCS, indicating a lesser BCS average in the animals with the greatest production $(\mathrm{p}<0.05)$. We observed losses in the BCS amongst the thirty days prepartum, on the day of the calving and the 15 days postpartum $(3.03 \pm 0.31,2.8 \pm 0.21$ and $2.55 \pm 0.28$ respectively), $(\mathrm{p}<0.05)$. On the 15 th day postpartum the BCS did not show any variations $(\mathrm{p}>0.05)$. This result was similar to those described by Lago et al. ${ }^{(10)}$, where it was observed that the NEB was the most accentuated in the first three weeks postpartum through the measurement of higher levels of beta-hydroxybutyrate and where it was also observed that there was a higher loss of BCS in the animals with greater body conditions for calving. 


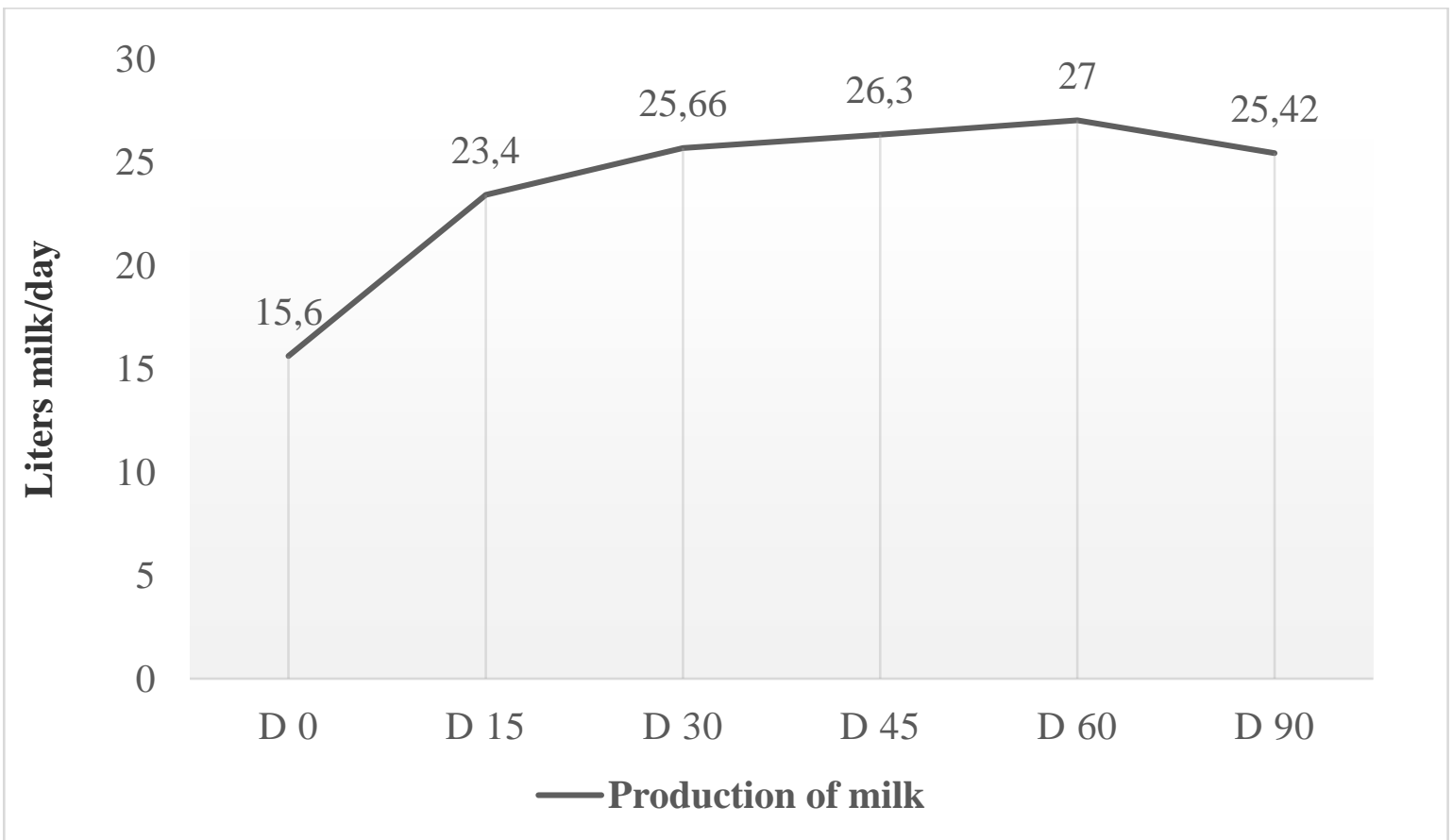

Figures 01: Production of milk from the animals studied up to the 90th day postpartum.

The ideal BCS for dairy cows vary depending on the phase of production and an exact number cannot be used as a stick rule ${ }^{(11)}$. Dry cows that present high BCS that is higher than four and below three, have a greater chance of developing metabolic problems in the postpartum period therefore the adequate BCS for this period varies between 3.25 and $3.75^{(12)}$. Up to the 30th day postpartum, we observed significant losses in the average BCS for the animals that were studies being $3.03 \pm 0.31,2.8 \pm$ $0.21,2.55 \pm 0.28$ e $2.49 \pm 0.27$ in the evaluations carried out 30 days prepartum, then on the calving and 15 and 30 days postpartum, respectively $(\mathrm{p}<0.05)$. From then on, there were no alterations in the average BCS being $2.45 \pm 0.23,2.42 \pm 0.23$ and $2.42 \pm$ 0.24 , at 45,60 and 90 days postpartum respectively ( $p>0.05$ ). The Figure 02 indicates the variation of BCS in the animals during the period of the study.

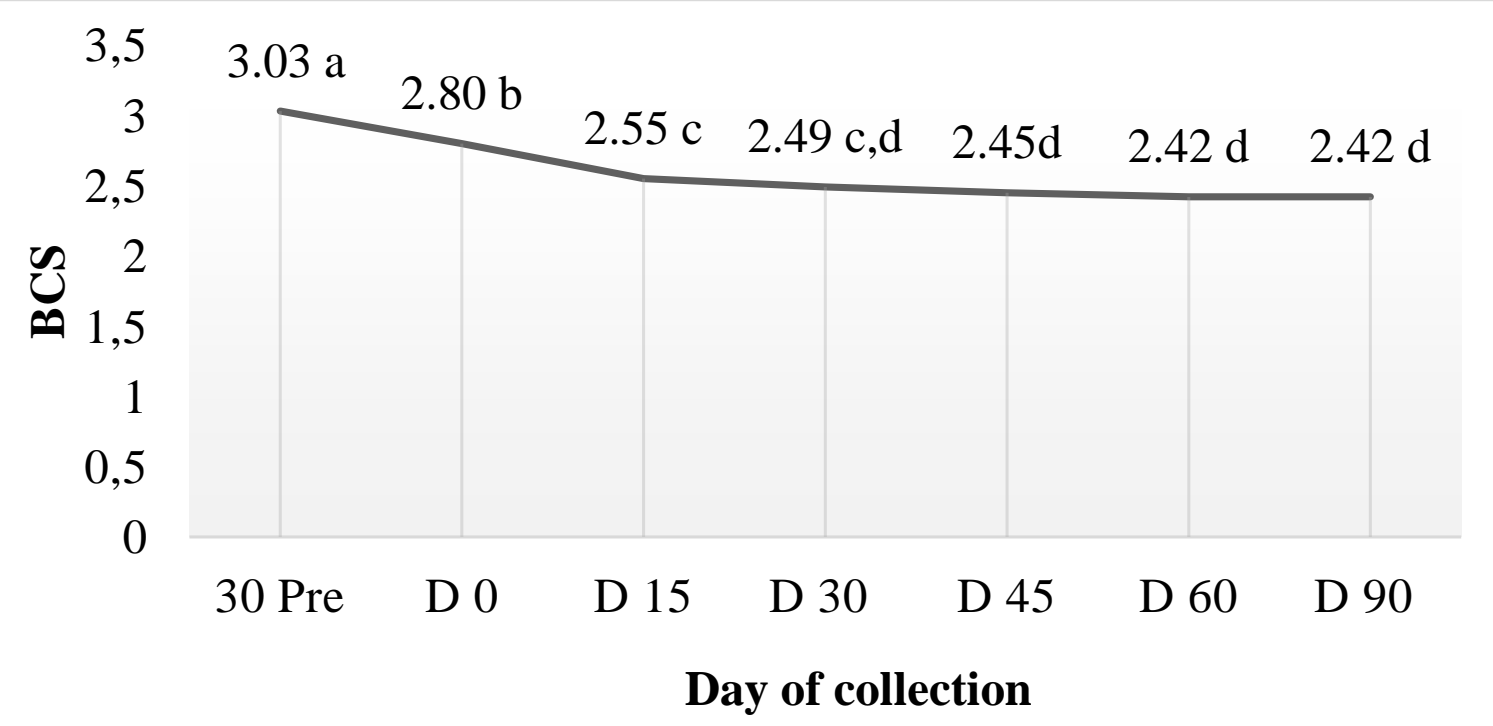

Figures 02: Variation of the BCS in the animals evaluated 30 days prepartum, then at calving and then 15, 30, 45, 60 and 90 days postpartum. ${ }^{\mathrm{a}, \mathrm{b}, \mathrm{c}, \mathrm{d}}$ Averages followed by different letters that differ $(\mathrm{p}<0.05)$ 
The understood step between the dry period and the prepartum period has the objective of re-establishing the body reserves of the cow preparing it for another lactation and maximizing the production of milk which reduces the occurrence of ailments and problems at calving and postpartum. In this aspect, it is highly undesirable to have any loss of body reserves ${ }^{(12)}$, which did not take place in this study. The loss of the average BCS for the animals that were studied at the prepartum period up to 30 days postpartum, possibly indicates a mobilization of body reserves due to, for example, inadequate diet provided to the animals during the dry period. Already during the last 2-3 weeks of gestation the grain level is gradually increased, and the diet is adjusted to increased requirements for energy and nutrients like metabolizable protein, vitamins, and minerals. While avoiding excesses of energy intake in order to control BCS around parturition ${ }^{(13)}$, increasing amounts of grain during this period allow a smooth adaptation of the rumen epithelium structures and microbiota to grain-rich diets after parturition ${ }^{(14)}$.

During the period of study, we observed the occurrences of calving in the three seasons on of the year (spring, summer and autumn). It was observed that there was an average BCS in the animals that gave calving in the summer, spring and autumn respectively being $2.67 \pm 0.19,2.58 \pm 0.15$ and $2.5 \pm 0.17(\mathrm{p}<0.05)$. Figure 3 shows the BCS average of the animals that gave calving in different seasons of the year.

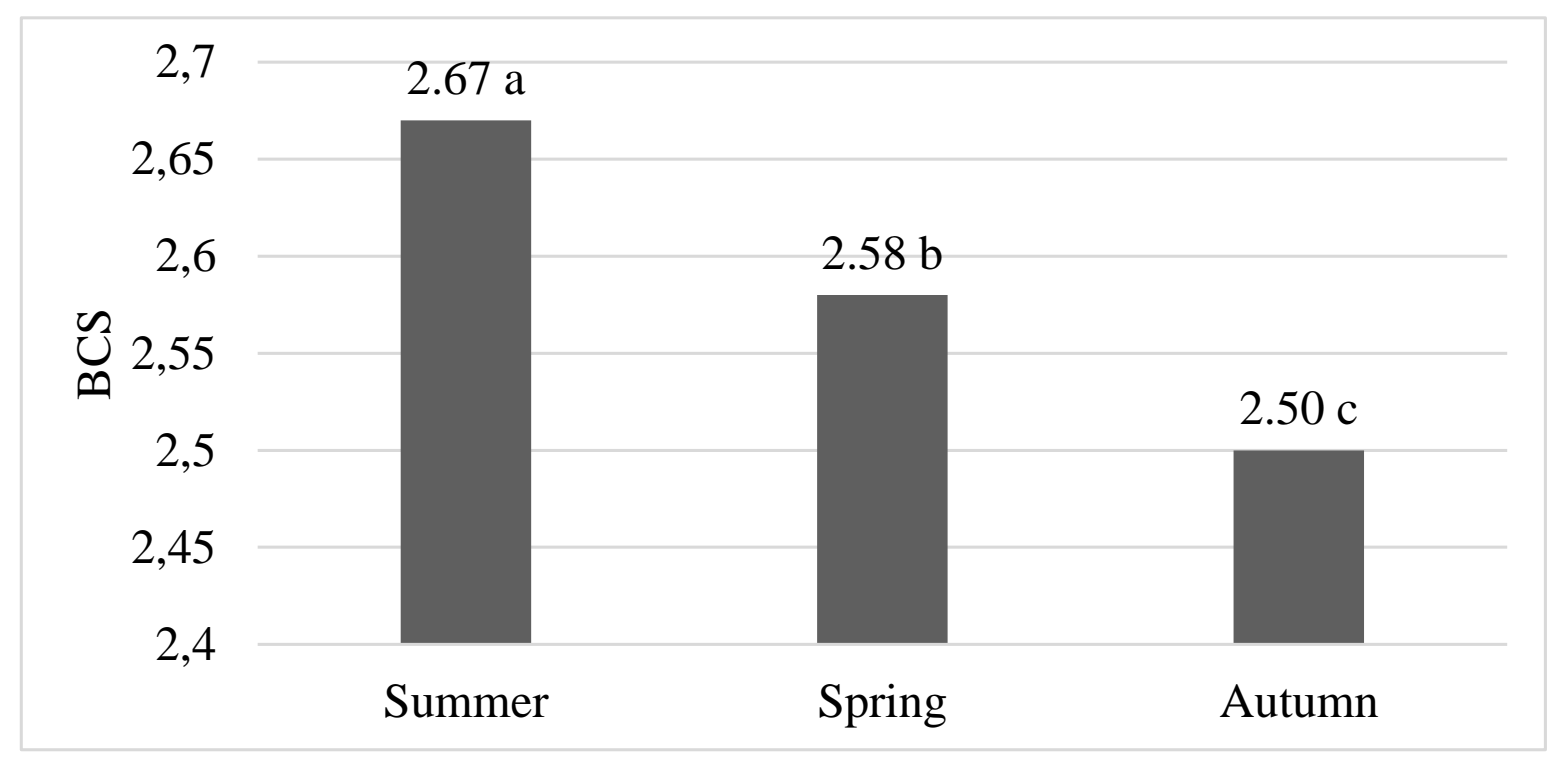

Figure 03: BCS average of the animals that gave calving in different seasons of the year. ${ }^{a, b, c, d}$ Averages followed by different letters that differ $(\mathrm{p}<0.05)$

The difference in the BCS average for the animals that gave calving in different seasons in the year is possibly related to the period of the lack of fodder that was the case in region that was studied. The lack of fodder occurs in the month of October due to the reduction of the photo-period and the average temperatures. This starts the decline in the production of fodder for the summer before the establishment of the winter fodder, meaning less availability and nutritional quality in the fodder ${ }^{(15)}$.

The uterine involution was observed in $30.88 \%$ (21/68) of the female at the 30th day postpartum and in $76.47 \%(52 / 68)$ at the 60th day. $23.52 \%(16 / 68)$ of the animals did not show complete uterine involution characterized by alterations in the position of $37.5 \%(6 / 16)$ of the animals that presented abdominal cavities in the uterus as well as in the symmetry $25 \%$ (4/16 asymmetric) in the size and/or the presence of secretion $37.5 \%$ (6/16 the average size). 
The complete uterine involution can suffer variations in accordance with the race and the way how the cattle is managed. Zain et al. ${ }^{(16)}$ define the average period of 30 to 35 days for complete involution in cows that are of the Dutch breed being earlier in the cows that were cross breeds ${ }^{15)}$. However, Lopes ${ }^{(18)}$ notes that the uterine involution occurs on average at the 40.33th day for Dutch cows as it gets closer to the time that has elapsed for uterine involution in animals of this study.

The time for uterine involution should be taken into account in the establishment of the voluntary waiting period (VWP) that is necessary for the return of reproductive activities. The VWP showed variation being $45-60$ days $^{(19)}$ being adjusted in accordance with the property between 30 and 90 days ${ }^{(20,21)}$. The establishment of the VWP should consider the physiological needs in relation to the reproductive organs of the cow for reproducing and involution, as longer periods show better rates of conception at the first cover owing to better uterine recuperation as well as shorter periods, reducing the rate of gestation on the first cover ${ }^{(20)}$. The VWP adopted in the properties was 60 days and the rate of conception at the first insemination was $41 \%$, a value considered adequate for the cattle type ${ }^{(22)}$.

We noted the presence of the corpus luteum in 27.94\% (19/68) and 72.05\% (49/68) of the animals at the 30th and 60th day postpartum, indicating the return of the ovarian cyclicality of these animals. The absence of the cyclicality in the postpartum period in bovines is due to the nutritional state before and after calving. The occurrence of NEB and the high production of milk has the ability to influence, in a negative way, the functioning of the hypothalamic and hypophysis axis ${ }^{(23)}$. However Butler ${ }^{(24)}$ has noted that cows with low BCS are those that are more likely to have extensions in the absences of mating during the postpartum period. In this study the loss of BCS was not correlated to the duration of this period postpartum ( $p>0.05 \%)$. However, animals that conceived in the summer had higher BCS and showed a less period of service $(\mathrm{p}<0.05)$.

The presence of the ovarian corpus luteum was less in the animals that had delays on their uterine involution $(\mathrm{p}<0.05)$. Martins et al. ${ }^{(25)}$, after having evaluated the puberty of Dutch cows, observed delays in the return of cyclicality in the cows and they noted uterine infections.

Female primiparas had the highest period of service when compared with the those that produced more offspring being $134.7 \pm 40.9$ and $107.6 \pm 34.1$, respectively $(p<0.05)$. On the other hand, they presented periods of uterine involution that were similar $134.7 \pm 40.9$ and $107.6 \pm 34.1$, respectively $(\mathrm{p}<0.05)$. However, the number of services per conception did not differ in relation to the number of calving $(p>0.05)$. This was different to the reports from Zhang et al. ${ }^{(26)}$, where primiparas cows showed greater time for uterine involution and for their first ovulation in the postpartum period.

The number of services per conception was greater in the animals conceived in the winter and autumn than those inseminated in the summer and spring $(\mathrm{p}<0.05)$, with $2.08 \pm 1.01,1.96 \pm 0.98,1.66 \pm 0.74$ and $1.54 \pm 0.65$ services/conception being observed in the winter seasons for autumn, spring and summer respectively (Figure 4). Silva et al. ${ }^{(27)}$ noted the difference in the rate of conception in the different seasons in the year. 


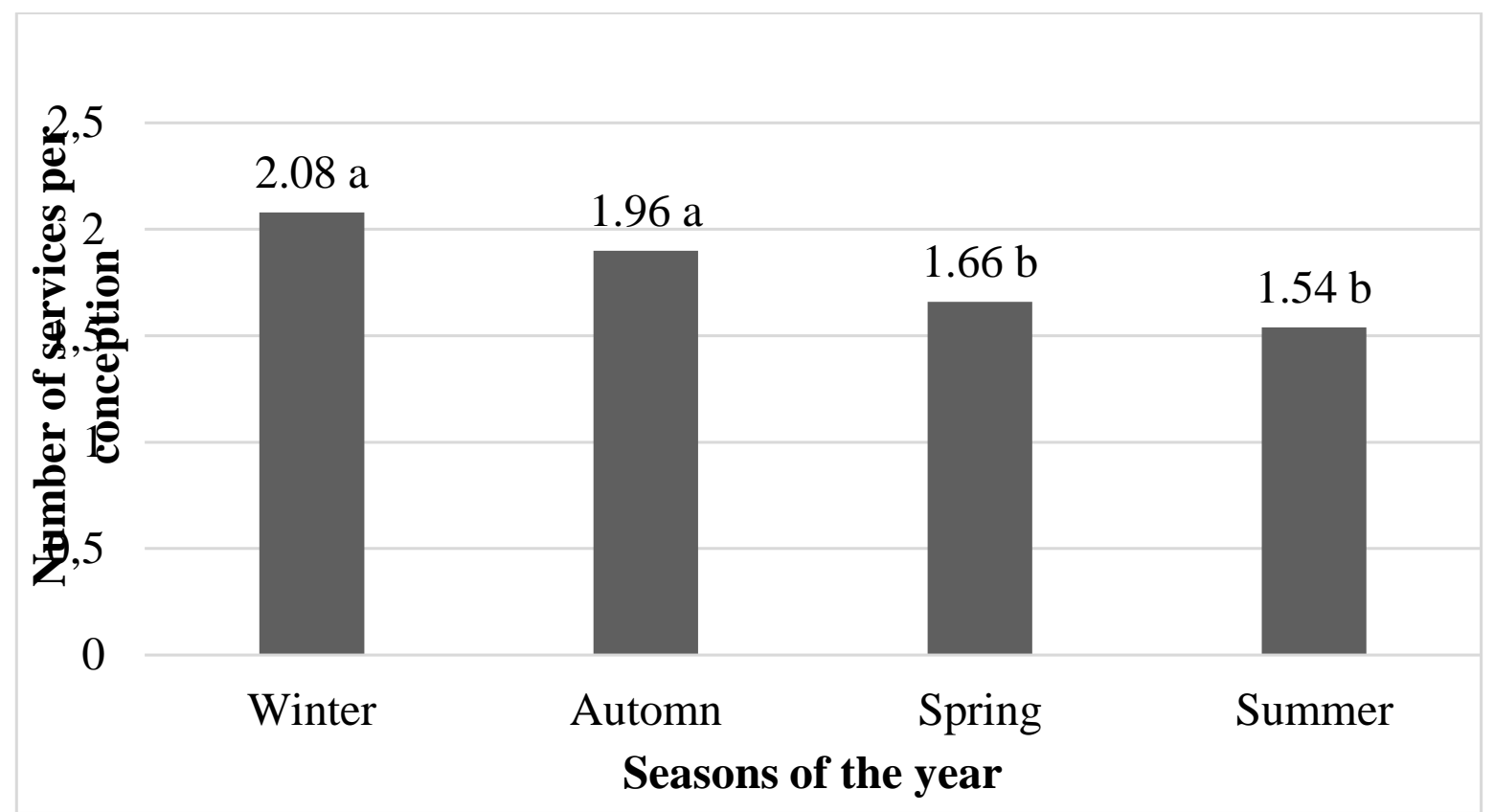

Figure 04: The number of services per conception that were observed in the animals in the different seasons of the year. ${ }^{a, b}$ Averages followed by the different letters that differed $(\mathrm{p}<0.05)$

Different authors noted lesser rates of fertility in the hot seasons and they attributed the disorders, such as low conception rate and early embryo mortality, to the effects of the caloric stress principally in the tropical regions ${ }^{(28,29,30)}$. However, in this work the fertility was higher in the hot months possibly due to the higher availability and quality of fodder during this period and as a consequence, better BCS.

A lower number of services per conception was observed in the animals that had higher productions $(\mathrm{p}<0.05)$. This condition was different to that which was observed by Silva et al. ${ }^{(27)}$, where the rate of conception did not vary in accordance with the level of the production of milk.

The average of calving intervals (IEP) for the animals that were studied was $12.9 \pm 3.6$ months which was less than what was presented by Ferreira and Miranda ${ }^{(31)}$ who note an IEP that was higher than 18 months in similar conditions to this study. On comparing the IEP with the conception season, we note that the temperature for seasons that were quite mild (winter and autumn) the IEP were higher than those observed in the hot season (summer and winter) ( $<<0.05$ ), with $401.1 \pm 32.2,395.3 \pm$ 43.6, $385.3 \pm 31.2$ and $367 \pm 27.9$ days for the winter, autumn, summer and spring seasons respectively. This was possibly due to the availability of food that was observed in the hot seasons.

The IEP is the reflex of the period of service being an important tool for the evaluation of the reproductive program of the cattle which should be kept between 12 and 13 months with the animals that are persistently low in lactation, as the time can be reduced $^{(32)}$. Intervals below 13 months ensures greater milk production and longer lactation periods which was observed in the animals that were studied.

\section{CONCLUSION}

Under the conditions of this study, it was concluded that the period of service and the average IEP of the animals that were studied met the desired parameters for dairy cattle. However, it was observed that these parameters varied in accordance with the 
season of the year and with the BCS of the animals that were studied, indication possible failures in the nutritional management of the animals in the seasons where there is less availability of fodder and in specific situations as the prepartum period.

\section{REFERENCES}

1. IBGE - Instituto Brasileiro de Geografia e Estatística. Indicadores IBGE Estatística da Produção Pecuária. Junho de 2015.

2. DERAL - Departamento de Economia Rural. Cultura - Análise da Conjuntura Agropecuária 2013/14. Março 2014. Disponível em: http://www.agricultura.pr.gov.br/arquivos/File/deral/Prognosticos/leite_2013_14.pdf. Acesso em: 02 out. 2015.

3. Leroy JL, Opsomer G, Van Soom A, et al. Reduced Fertility in High-yielding Dairy Cows: Are the Oocyte and Embryo in Danger? Part I The Importance of Negative Energy Balance and Altered Corpus Luteum Function to the Reduction of Oocyte and Embryo Quality in Highyielding Dairy Cows. Reprod Domest Anim. 2008;43(5):612-622.

4. Emerick LL, Dias JC, Gonçalves PEM. Retorno da atividade ovariana luteal cíclica de vacas de corte no pós-parto: uma revisão. Rev Bras Reprod Anim. 2010;33(4)203-212.

5. Lucy MC. Mechanisms linking nutrition and reproduction in postpartum cows. Reprod Suppl. 2003;61:415-427.

6. Pires AV, Biehl MV, Susin I, et al. Interrelações entre nutrição e reprodução: fatores que potencializam o desempenho reprodutivo. In: SIMBOV MT-SIMPÓSIO MATOGROSSENSE DE BOVINOCULTURA DE CORTE, 1., 2011, Cuiabá, Anais...Cuiabá, 2011.

7. Edmonson AJ, Lean IJ, Weaver LD. A body condition scoring chat for Holstein dairy cows. J Dairy Sci. 1989;72(1):68-78.

8. Parré JL, Bánkuti SMS, Zanmaria NA. Perfil socioeconômico de produtores de leite da Região Sudoeste do Paraná: um estudo a partir de diferentes níveis de produtividade. Rev Econ Agroneg. 2011;9(2): 275-300.

9. IAPAR -INSTITUTO AGRONÔMICO DO PARANÁ. Cartas Climáticas do ParanáDisponível em <http://www.iapar.br/modules/conteudo/conteudo.php?conteudo=597>. Acesso em 13 de Outubro de 2015.

10. Lago EP, Pires AV, Susin I, et al. Efeito da Condição Corporal ao Parto sobre Alguns Parâmetros do Metabolismo Energético, Produção de Leite e Incidência de Doenças no PósParto de Vacas Leiteiras. Rev. Bras. Zootec. 2001;30(5):1544-1549.

11. Patton RA, Bucholtz HF, Schmidt MK, et al. Body Condition Scoring. A management tool. Department of Animal Science Michigan State University.1988.

12. Ferguson JD, Byers D, Ferry J. Round table discussion: body condition of lactating cows. Agr Pract. 1994;15(4):17-21.

13. Drackley JK, Cardoso FC. Prepartum and postpartum nutritional management to optimize fertility in high-yielding dairy cows in confined TMR systems. Animal. 2014; 8:5-14.

14. Zebeli,Q, Ghareeb K, Humer E, Metzler-Zebeli BU, Besenfelder U. Nutrition, rumen health and inflammation in the transition period and their role on overall health and fertility in dairy cows. Res. Vet. Science. 2015; 103:126-136.

15. Pin EA, Cechin F, Pigosso M. Sistemas de Sobressemeadura e Dinâmica Produtiva de Forrageiras Temperadas sobre a Tífton 85. Faz Ciência. 2014;16(23):84-93.

16. Zain AE, Nakao T, Raouf MA, et al. Factors in the resumption of ovarian activity and uterine involution in postpartum dairy cows. Anim Reprod Sci. 1995;38(3):203-214.

17. Araújo PG, Pizelli GN, Carvalho MR, Meneguelli CA. Involução uterina e atividade ovariana na vaca leiteira após o parto. Pesq Agropec Bras. 1974;9(7):1-6.

18. Lopes DT. Efeitos da utilização de prostaglandina F2 $\alpha$ durante o puerpério precoce sobre a eficiência produtiva de vacas leiteiras. 2007. 60f. Dissertação (Mestrado em Medicina Veterinária) - Escola de Veterinária, Universidade Federal de Goiás, Goiânia, GO, 2007.

19. Rocha A, Rocha S, Carvalheira J. Reproductive parameters and efficiency of inseminators in dairy farms in Portugal. Reprod Domest Anim. 2001;36(6):319-324.

20. Chebel RC. Voluntary waiting period: How soon is too soon, and how late is too late? Western Dairy News. 2008;8(3):89-90. 
21. Dejarnette JM, Sattler CG, Marshall CE, et al. Voluntary waiting period management practices in dairy herds participating in a progeny test program. J Dairy Sci. 2007;90(2):10731079.

22. Carneiro MA, Bergamaschi M, Machado R, Barbosa RT. Eficiência reprodutiva das vacas leiteiras. Circular Técnica 64-EMBRAPA, 2010. Disponível em: http://www.infoteca.cnptia.embrapa.br/infoteca/bitstream/doc/880245/1/Circular642.pdf.

23. Williams GL, Gazal OS, Guzman Vega GA, et al. Mechanisms regulating sucklingmediated anovulation in the cow. Anim Reprod Scie. 1996;42(1):289-297.

24. Butler WR. Energy balance relationships with follicular development, ovulation and fertility in postpartum dairy cows. Livest Prod Sci. 2003;83(2):211-218.

25. Martins TM, Santos RL, Paixão TA, et al. Aspectos reprodutivos e produtivos de vacas da raça Holandesa com puerpério normal ou patológico. Arq Bras Med Vet Zootec. 2013;65(5):1348-1356.

26. Zhang J, Deng LX, Zhang HL, et al. Effects of parity on uterine involution and resumption of ovarian activities in postpartum Chinese Holstein dairy cows. J Dairy Sci. 2010;93(5):19791986.

27. Silva NC, Leão KM, Marques TC, et al. Taxa de concepção de vacas leiteiras submetidas à inseminação artificial em tempo fixo em diferentes épocas do ano. Biosc J. 2014;30(4):11771182.

28. Badinga L, Collier RJ, Thatcher WW, Wilcox CJ. Effects of Climatic and Management Factors on Conception Rate of Dairy Cattle in Subtropical Environment. J Dairy Sci. 1985;68(1):78-85.

29. Cavestany D, El-Whishy AB, Foot RH. Effect of season and fertility of Holstein cattle. $J$ Dairy Sci. 1985;68(6):1471-1478.

30. Ricci GD, Orsi AM, Domingues PF. Estresse calórico e suas interferências no ciclo de produção de vacas de leite - Revisão. Vet Zoo. 2013;20(3):9-17.

31. Ferreira AM, Miranda JEC. Medidas de eficiência da atividade leiteira: índices zootécnicos para rebanhos leiteiros. Comunicado Técnico 54 - Embrapa, 2007. Disponível em: http://www.cnpgl.embrapa.br/totem/conteudo/Outros_assuntos/Comunicado_Tecnico/COT54_ Medidas_de_eficiencia_da_ativ_leiteira_indices_zootecnicos.pdf

32. Nebel RL. The key to a successful reproductive management program. Adv Dairy Tech. 2003;15:1-16. 